\title{
BEHAVIOR OF HALF-SIB PROGENIES OF CORIANDER
}

\section{COMPORTAMENTO DE PROGENNIES MEIOS-IRMÃOS DE COENTRO}

\author{
Gustavo Hugo Ferreira de OLIVEIRA ${ }^{1}$; Victor Hugo Barreto da COSTA ${ }^{2}$; \\ Alysson Jalles da SILVA ${ }^{3}$; José Luiz Sandes de CARVALHO FILHO \\ 1. Engenheiro Agrônomo, Doutorando, Programa de Pós Graduação em Agronomia (Genética e Melhoramento de Plantas), \\ Universidade Estadual Paulista "Júlio de Mesquita Filho" - UNESP, Jaboticabal, SP, Brasil. gustavo.melhorista@ gmail.com; 2. \\ Engenheiro Agrônomo, Universidade Federal Rural de Pernambuco - UFRPE, Recife, PE, Brasil; 3. Engenheiro Agrônomo, \\ Doutorando, Programa de Pós Graduação em Agronomia (Genética e Melhoramento de Plantas), Universidade Estadual Paulista "Júlio \\ de Mesquita Filho" - UNESP, Jaboticabal, SP, Brasil; 4. Professor, Doutor, Universidade Federal Rural de Pernambuco - UFRPE, \\ Recife, PE, Brasil.
}

\begin{abstract}
This work evaluated the behavior of coriander half-sib progenies (Coriandrum sativum L.) regarding their agronomic traits. The study was developed in a greenhouse in the Universidade Federal Rural de Pernambuco, PE, Brazil. The experiment was designed as augmented block design with 26 coriander genotypes, of which 24 were coriander half-sib treatments, and two control treatments, 'Verdão' and 'Tabocas'. These progenies were selected from four cycles of phenotypic recurrent selection from the 'Verdão' population, which were selected for later bolting. Plant height and canopy diameter were evaluated in the field, and shoot fresh mass. There were significant differences between the treatment means for all variables analyzed. Regarding analysis of variance and SNK test, there is available variability to select half-sib progenies. Genotypes $\mathrm{C}_{4}-014, \mathrm{C}_{4}-015, \mathrm{C}_{4}-016$, and $\mathrm{C}_{4}-018$ had promising productivity compared to the commercial control varieties. The broad-sense heritability values were $77.3,81.5$ and $95.8 \%$ for canopy diameter, shoot fresh mass, and plant height, respectively. This result showed that the majority of phenotypic variance is genetic. Therefore, these genotypes may be used in coriander breeding programs of recurrent selection to obtain cultivars adapted to tropical conditions.
\end{abstract}

KEYWORDS: Coriandrum sativum L: Augmented blocks.'Recurrent selection.

\section{INTRODUCTION}

Horticulture has innovated in several aspects and established its importance by improving land use, encouraging crop diversification and providing healthy food to the population (BISOGNIN et al., 2011).

Coriander, Coriandrum sativum L., has been a major component of horticulture in Brazil and worldwide. It originated in Europe, where it has been cultivated for more than 3,000 years. Its leaves and fruits are highly consumed especially as condiment (NASCIMENTO; PEREIRA 2005).

In Brazil, it is the second most important leaf vegetable next to lettuce and is cultivated during the entire year. It is consumed mainly in the North and Northeast regions, but it is currently expanding to Center-Southern Brazil (BERTINI et al., 2010; LUZ et al., 2012).

The majority of coriander scientific papers found in the literature focus on the phytotechnical aspects and evaluate fertilization, cultivar, and the environment. Few studies have focused on the development of new cultivars to compete with the ones already established on the market.

The Verdão cultivar, the market leader in Pernambuco and Brazil, has wide variability (MELO et al., 2009a) and high potential to explore the new cultivars in studies of progenies. Some farmers dislike some traits of the Verdão cultivar such as early bolting and flowering time. However, it has an excellent rusticity, very vigorous dark green leaves, good resistance to diseases, traits that can be explored in plant breeding programs to obtain genetic gains.

In the current coriander breeding programs, the genetic gain is based on the selection method, which results from selecting the best individuals to be used as parents in the next generation (BERTINI et al., 2010; MELO et al., 2009b). However, this option is not the best to genetically improve the population because the selection of individual plants tends to be strongly influenced by the environment. Therefore, to reduce the influence of the environment, the progenies, instead of individual plants, are more commonly used in allogamous plant breeding to increase heritability and selection gain (BORÉM; MIRANDA, 2013). Thus, the parent should be evaluated and chosen based on their progenies. This process can be used to estimate the population variability and the nature of the phenotypic variation that can be considered the genetic identity of a population.

The estimation of the genetic parameters is important as it provides information about the nature of gene interactions involved in the 
inheritance of a particular trait and it consolidates the breeding programs. To this end, there are several ways to estimate the parameters based on progeny testing, among which stands out the analysis of variance, whose components are obtained by the decomposition of the mean squares based on the expected mean square values (VENCOSVSKY; BARRIGA, 1992).

Thus, this study evaluated the behavior of coriander half-sib progenies, derived from the Verdão cultivar, regarding agronomical traits.

\section{MATERIAL AND METHODS}

The study was developed in the horticulture sector of the Department of Agriculture of the Universidade Federal Rural de Pernambuco, in Pernambuco State, Brazil, (8'54'47' 'S, 34 $54^{\prime} 47^{\prime}$ ' $\mathrm{W}$, and 6 meters altitude) in March 2012. In the sowing stage, polystyrene trays with 200 cells, surrounded with screens and covered with a 150-micron transparent polyethylene film, were placed in a closed greenhouse. Later, the seedlings were transplanted to $1 \mathrm{~m} \times 10 \mathrm{~m}$ beds and fertilized with cattle manure.

The experimental design used was the Federer augmented block design with four replications, with 24 regular treatments, coriander half-sib progenies and two common treatments, 'Verdão' and 'Tabocas'. The progenies originated from 4 cycles of phenotypic recurrent selection performed on a population of the cultivar Verdão, which had been selected for later-bolting.

The seeds were sown on expanded polystyrene trays containing commercial substrate, at the density of four seeds per cell. Each tray had six different coriander progenies, one treatment every two rows, totaling 16 plants for each progeny.

The Verdão and Tabocas cultivars were planted in all trays as control. Thinning took place 10 days after transplanting. The Transplanting was made with seven days after seeding. The irrigation using automatic fogging systems was performed three times daily at the seeding stage, taking into consideration the temperature and plant needs. The spacing at transplanting was $0.10 \times 0.20 \mathrm{~cm}$ in $1 \mathrm{~m}^{2}$ plots, with 12 plants per plot.

After the seedlings were transplanted to the beds, the plants were irrigated by aspersion throughout the development stage, three times a day. The beds were fertilized with ammonium sulfate 20 g.m $\mathrm{m}^{-2}$ and $10 \mathrm{~g} . \mathrm{m}^{-2}$ potassium nitrate, as indicated by soil analysis, and fertilized 10 days after transplanting again.
The following agronomical traits were measured per plot, plant height, canopy diameter, and shoot fresh mass, using scalimeter, caliper, and balance, respectively. At harvest, plant height was measured as the distance from the soil to the newest leaf while canopy diameter was measured with a precision caliper. After the measurements, all plants were collected and sent to the laboratory to determine shoot fresh mass. The means per plot were calculated for all variables.

The analysis of variance was performed using the $\mathrm{SAS}^{\circledR}$ software (SAS Institute Inc., 2009), according to the following model:

$$
y_{\mathrm{IJK}}=\mu+\beta_{\mathrm{j}}+\mathrm{t}_{\mathrm{k}}+\mathrm{g}_{\mathrm{i}(\mathrm{k})}+\varepsilon_{\mathrm{ij}}
$$

Where:

$y_{\mathrm{IJK}}=$ is the observed response of the $i^{\text {th }}$ treatment in the $\mathrm{j}^{\text {th }}$ block (total $\mathrm{n}$ observations);

$\mu=$ is the constant common to all observations (general reference to all information);

$\beta_{j}=$ is the effect of the $\mathrm{j}^{\text {th }}$ block ( $\mathrm{j}=1,2,3$ and 4$)$;

$t_{\mathrm{k}}=$ is the effect of $\mathrm{k}^{\text {th }}$ treatment with $\mathrm{k}=1$ or 2 , according to treatment, control (C) or progeny $(\mathrm{P})$, respectively;

$\mathrm{g}_{\mathrm{i}(\mathrm{k})}=$ is the effect of progeny $\mathrm{i}$ within the $\mathrm{k}^{\mathrm{th}}$ treatment; and

$\varepsilon_{\mathrm{ij}}=$ is the random error associated with the experimental plot with the $\mathrm{i}^{\text {th }}$ treatment in the $\mathrm{j}^{\text {th }}$ block, normal and independently distributed, with zero mean and variance $\sigma_{\mathrm{e}}^{2}\left(\mathbf{R}=\mathbf{I} \sigma_{\mathrm{e}}^{2}\right)$.

The means were submitted to analysis of normality using the PROC UNIVARIATE of SAS ${ }^{\circledR}$ statistical program and the Shapiro-Wilk method. The data that were not normally distributed were transformed using the PROC TRANSREG, following the methodology proposed by Box and Cox (1964). The adjusted means were compared by the SNK test (Student Newman Keuls). The PROC TREE, PROC CLUSTER and PROC DISTANCE of SAS ${ }^{\circledR}$ (SAS, 2009) software were used to produce the dendrogram, cluster, and generate the distances, respectively. The cophenetic correlation coefficient was calculated to determine the relationship between the Euclidian and cophenetic matrices.

Genetic, phenotypic, and environmental parameters were obtained using the Genes Software (Cruz, 2013).

\section{RESULTS AND DISCUSSION}

The analysis of variance showed a significant difference in at least one contrast 
between the progenies for plant height $(\mathrm{P}<0.05)$.

(Table 1).

All other variables were not significantly different

Table 1. Analysis of variance for the characters plant height, canopy diameter and fresh mass of shoot of halfsib progenies derived from the cultivar Verdão, Recife, UFRPE, 2012.

\begin{tabular}{lcccc}
\hline \multirow{2}{*}{ Source of Variation } & DF & \multicolumn{3}{c}{ Mean Square (MS) } \\
\cline { 3 - 5 } & & Plant height & Canopy diameter & Fresh mass of shoot \\
\hline Block & 3 & $78.9048^{* *}$ & $72.4809^{*}$ & $403.1250^{* *}$ \\
Type & 1 & $16.6500^{*}$ & $0.2310^{\mathrm{ns}}$ & $26.0416^{\mathrm{ns}}$ \\
Progeny (Type) & 24 & $9.6539^{*}$ & $7.6330^{\mathrm{ns}}$ & $44.0972^{\mathrm{ns}}$ \\
$\quad$ Control Variety & 1 & $1.1250^{\mathrm{ns}}$ & $6.1250^{\mathrm{ns}}$ & $3.1250^{\mathrm{ns}}$ \\
& & & & \\
$\quad$ Progeny & 23 & $10.0247^{*}$ & $7.6986^{\mathrm{ns}}$ & $45.8786^{\mathrm{ns}}$ \\
Error & 3 & 1.0910 & $6.1250^{\mathrm{ns}}$ & 19.7916 \\
Corrected total & 31 & & & \\
\hline
\end{tabular}

** - Significant at $1 \%, *$ - Significant at 5\%, NS - Non-Significant by F test.

Even though there was no significant differences observed among treatments using $\mathrm{F}$ test, the comparison of means revealed differences among tested genotypes. Thus, the multiple comparison procedure SNK revealed significant difference among means of progenies for all variables (Table 2).

The average plant height trait for the $\mathrm{C} 4$ 014, C4-015, C4-016 and C4-018 treatments was significantly greater and ranged between 18.78 and $20.95 \mathrm{~cm}$, higher than the $14.58 \mathrm{~cm}$ and $15.33 \mathrm{~cm}$ values obtained for the control, Tabocas and Verdão, respectively. Pereira et al. (2011) studied coriander fertilized with compost and reported maximum plant height of about $14.6 \mathrm{~cm}$ for Verdão. Also, Nunes et al. (2007) investigated organic fertilization and obtained plant height of $29.6 \mathrm{~cm}$ for coriander cv. Verdão. These results show not only that the maximum height values obtained in the present study are within the expected range, but also the great genetic potential of these four treatments, $\mathrm{C}_{4}-014, \mathrm{C}_{4}-015, \mathrm{C}_{4}-016$ and $\mathrm{C}_{4}-018$. The above authors worked with organic compounds, which probably increased the potential response of these cultivars. Likewise, Oliveira et al. (2002) showed that the response to fertilization in coriander is linear since plant height increased with the increase of mineral and organic fertilizer, based on bovine manure.

The canopy diameter for the $\mathrm{C}_{4}-015$ and $\mathrm{C}_{4}{ }^{-}$ 016 treatments did not differ and was $16.71 \mathrm{~cm}$ and $15.37 \mathrm{~cm}$ on average, respectively. These values were higher than those obtained for the other treatments and the control varieties, which were $9.75 \mathrm{~cm}$ and $11.50 \mathrm{~cm}$ for Verdão and Tabocas, respectively. Even though these treatment averages were higher than the control varieties, they did not differ significantly by the SNK test, probably because this trait is highly influenced by the environment. According to Bertini et al. (2010), these traits are of paramount importance to the culture of coriander, mainly for fruit production.

Shoot fresh mass is considered an important trait when searching for genotypes that may contribute favorably to the key leaf production trait. The $\mathrm{C}_{4}-008, \mathrm{C}_{4}-009, \mathrm{C}_{4}-014, \mathrm{C}_{4}-015, \mathrm{C}_{4}-016$ and $\mathrm{C}_{4}-018$ treatments had the highest averages, ranging from 24.37 g.plant ${ }^{-1}$ to 34.37 g.plant ${ }^{-1}$. These progenies did not differ from the control varieties, Verdão and Tabocas, showing great potential, in terms of the means value, for the production of shoot fresh mass. Oliveira et al. (2007) reported that the Verdão cultivar was superior to all progenies regarding this trait. This result shows the great genetic potential of the progenies evaluated in this study and enhances the possibility of high genetic gain of the recurrent selection method applied to these progenies since the populations were derived from the Verdão cv.

In general, the $\mathrm{C}_{4}-015$ progeny was superior to the other treatments regarding the averages of all evaluated traits (Table 2) and even better than the control varieties.

Regarding the genetic parameters estimated to coriander production traits (Table 3), the genotypic variance was high and higher than the environmental variance for the plant height and shoot fresh mass traits, showing that the expression of these traits in coriander production is attributed mainly to the genetic effects. Thus, there is the possibility of successful selection of the best progenies in this environment.

The broad-sense heritability values were $77.3,81.5$ and $95.8 \%$ for canopy diameter, shoot 
fresh mass, and plant height, respectively (Table 3). These results showed that the majority of phenotypic variance is genetic, describing these traits as variables with high heritability estimate, indicating success in selection with recombination of these progenies in the next cycles of phenotypic recurrent selection.

Table 2. Adjusted means for the characters plant height, canopy diameter and fresh mass of shoot for 24 progenies derived from cultivar Verdão and 2 cultivars: Verdão and Tabocas, Recife, 2012.

\begin{tabular}{|c|c|c|c|}
\hline \multirow{2}{*}{ Genotype $\mathrm{C}_{4}$} & \multicolumn{3}{|c|}{ Means } \\
\hline & Plant height & Canopy diameter & Fresh mass of shoot \\
\hline $\mathrm{C}_{4}-001$ & $11.54 \mathrm{~cd}$ & 9.13 abcdefg & 16.87 abcdef \\
\hline $\mathrm{C}_{4}-002$ & $13.54 \mathrm{bcd}$ & 11.13 abcdef & $12.87 \mathrm{bcdef}$ \\
\hline $\mathrm{C}_{4}-003$ & $14.87 \mathrm{bcd}$ & 11.77 abcdef & 26.87 abcde \\
\hline $\mathrm{C}_{4}-004$ & $16.71 \mathrm{bc}$ & 13.28 abcde & $31.87 \mathrm{abcd}$ \\
\hline $\mathrm{C}_{4}-005$ & $14.54 \mathrm{bcd}$ & 13.63 abcde & 21.87 abcde \\
\hline $\mathrm{C}_{4}-006$ & $16.04 \mathrm{bcd}$ & 8.96 abcdefg & 26.87 abcde \\
\hline $\mathrm{C}_{4}-007$ & $14.54 \mathrm{bcd}$ & 12.96 abcde & 29.37 abcde \\
\hline $\mathrm{C}_{4}-008$ & $15.37 \mathrm{bcd}$ & 13.79 abcde & $34.37 \mathrm{a}$ \\
\hline $\mathrm{C}_{4}-009$ & $15.04 \mathrm{bcd}$ & 13.12 abcde & $34.37 \mathrm{a}$ \\
\hline $\mathrm{C}_{4}-010$ & $14.71 \mathrm{bcd}$ & 12.46 abcdef & 24.37 abcde \\
\hline $\mathrm{C}_{4}-011$ & $12.21 \mathrm{~cd}$ & 11.62 abcdef & 24.37 abcde \\
\hline $\mathrm{C}_{4}-012$ & $13.21 \mathrm{~cd}$ & 12.12 abcdef & 24.37 abcde \\
\hline $\mathrm{C}_{4}-013$ & $14.45 \mathrm{bcd}$ & 11.21 abcdef & 24.37 abcde \\
\hline $\mathrm{C}_{4}-014$ & $19.95 \mathrm{a}$ & 11.37 abcdef & 29.37 abcde \\
\hline $\mathrm{C}_{4}-015$ & $20.63 \mathrm{a}$ & $16.71 \mathrm{a}$ & $34.37 \mathrm{abc}$ \\
\hline $\mathrm{C}_{4}-016$ & $18.78 \mathrm{ab}$ & $15.37 \mathrm{ab}$ & 24.37 abcde \\
\hline $\mathrm{C}_{4}-017$ & $15.95 \mathrm{bcd}$ & $14.21 \mathrm{abcd}$ & 24.37 abcde \\
\hline $\mathrm{C}_{4}-018$ & $20.95 \mathrm{a}$ & $14.37 \mathrm{abc}$ & $34.37 \mathrm{abcd}$ \\
\hline $\mathrm{C}_{4}-019$ & $5.78 \mathrm{f}$ & $4.71 \mathrm{defg}$ & 4.37 ef \\
\hline $\mathrm{C}_{4}-020$ & $1.95 \mathrm{~g}$ & $0.04 \mathrm{~g}$ & $0.625 \mathrm{f}$ \\
\hline $\mathrm{C}_{4}-021$ & $8.28 \mathrm{e}$ & $1.21 \mathrm{fg}$ & 9.37 cdef \\
\hline $\mathrm{C}_{4}-022$ & $4.78 \mathrm{fg}$ & 4.04 efg & $4.37 \mathrm{ef}$ \\
\hline $\mathrm{C}_{4}-023$ & $4.45 \mathrm{fg}$ & 5.54 cdefg & $9.37 \mathrm{def}$ \\
\hline $\mathrm{C}_{4}-024$ & $10.62 \mathrm{de}$ & 7.54 bcdefg & 19.37 abcde \\
\hline Verdão & $15.33 \mathrm{bcd}$ & 9.75 abcdef & 23.75 abcde \\
\hline Tabocas & $14.58 \mathrm{bcd}$ & 11.5 abcdef & 25 abcde \\
\hline $\mathrm{CV}(\%)$ & 7.62 & 20.13 & 19.74 \\
\hline
\end{tabular}

* Means followed by same letters do not differ statically by SNK test $(\mathrm{P}<0.05)$. 
Table 3. Estimates of genetic parameters for characteristic plant height, canopy diameter and fresh weight of shoots of 24 sib progenies and 2 coriander cultivars derived from the cultivar Verdão, Recife, UFRPE, 2012.

\begin{tabular}{lccc}
\hline \multicolumn{1}{c}{$\begin{array}{c}\text { Genetic } \\
\text { Parameter }\end{array}$} & \multicolumn{2}{c}{ Evaluation } \\
\cline { 2 - 4 } & $\begin{array}{c}\text { Plant } \\
\text { height }\end{array}$ & $\begin{array}{c}\text { Canopy } \\
\text { diameter }\end{array}$ & $\begin{array}{c}\text { Fresh mass } \\
\text { of shoot }\end{array}$ \\
\hline$\sigma_{f}^{2}$ & 26.15 & & \\
$\sigma_{g}^{2}$ & 25.06 & 19.64 & 103.62 \\
$\sigma_{e}^{2}$ & 1.09 & 15.19 & 83.83 \\
$h^{2}(\%)$ & 95.82 & 4.44 & 19.79 \\
$C V_{g}$ & 37.66 & 77.35 & 80.90 \\
$C V_{g} / C V_{e}$ & 4.79 & 37.37 & 41.07 \\
$\bar{\mu}($ general) & 13.70 & 1.85 & 2.10 \\
$\bar{\mu}$ (progeny) & 13.29 & 10.47 & 22.81 \\
$\bar{\mu}$ (control variety) & 14.95 & 10.42 & 22.29 \\
\hline $\mathrm{h}^{2}=$ heritability in broad sense; $\sigma_{f}^{2}=$ Phenotypic variance; $\sigma_{g}^{2}=$ Genetic variance; $\sigma_{e}^{2}=$ Environmental variance; $\mathrm{CV}_{\mathrm{g}}=$ Genetic coefficient \\
of variation; $\bar{\mu}_{=\text {means }}$
\end{tabular}

Melo et al. (2009a) reported positive genetic correlation for the plant height and shoot fresh mass traits. This indicates that taller plants tend to have higher leaf mass while shorter plants tend to have lower shoot fresh mass, and earlier bolting. This data indicates possible genetic gain from these traits for direct or indirect selection, in which selection for one trait promotes gain in the other, given the high heritability estimates. The estimated heritability for plant height was higher than that reported by Melo et al. (2009a). The values for environmental variance found by Melo et al. (2009a) were higher than the values observed in this work, further reinforcing the notion that heritability is changeable and depends on the variability present in the study population and environmental control.

The $\mathrm{CV}_{\mathrm{g}} / \mathrm{CV}_{\mathrm{e}}$ ratio was larger than unit (Table 3) to plant height, canopy diameter and shoot fresh mass. This ratio informs about the use of a certain trait for selection because when the ratio is closer or higher than the unit, selection for the trait becomes more favorable. Thus, the lowest and the highest values were 1.848 and 4.793 for canopy diameter and plant height, respectively. These data also show that in the Verdão population, there is variability that can be exploited to obtain superior genotypes and that the method of recurrent selection applied to this population makes the process of obtaining these genotypes more efficient.

According to Vencosvsky (1987), ratio values approaching unit or higher, demonstrate a very favorable situation to obtain gains with the selection. Thus, higher values can bring significant gains in the first years of selection, which tend to decrease gradually during the successive selections (Alves et al., 2006). Thus, the highest value among the variables was 4.793 for plant height, showing that the practice of selection for this trait has the most favorable conditions for immediate genetic gains. On the other hand, parallel to this, it is possible to obtain gains for commercially important traits such as fresh mass, since this trait has strong correlation with plant height (MELO et al., 2009a).

Based on $C V_{g} / C V_{e}$ and heritability values, the method of phenotypic recurrent selection for all traits may have good gains and little difficulty in the conditions of the experiment. This selection method is widely used in the improvement of crosspollinated species. It allows an increase in the frequency of favorable alleles for the desired characters, in addition, to gains resulting from recurrent selection for different traits have been observed in studies performed with carrot (Silva; Vieira, 2010), onion (CRAMER, 2006), and potato (BENITES; PINTO, 2011). Recurrent selection allows significant improvement of the evaluated traits.

Among the traits evaluated in this study, shoot fresh mass can be used as the main trait to be evaluated in subsequent cycles of recurrent selection, and may be the main indicator to obtain coriander progenies with high commercial value. Different progenies of the control varieties 
were obtained by recurrent selection, including genotypes that differed from the parent (Verdão).

These results corroborate the UPGMA clustering dendrogram, reinforcing the difference. Five clusters were formed in the dendrogram, and the cophenetic correlation coefficient was 0.85 $(\mathrm{p}<0.0001)$. This result showed that the used cluster method characterized the real relationship among progenies.
The control variety Verdão was in cluster CII while the Tabocas was in cluster C-III. Clusters $\mathrm{C}$-II and C-IV might be selected in coriander plant breeding program to improve shoot fresh mass. Moreover, the progenies from cluster C-III can be selected aiming to increase the shoot fresh mass and plant height (Figure 1)

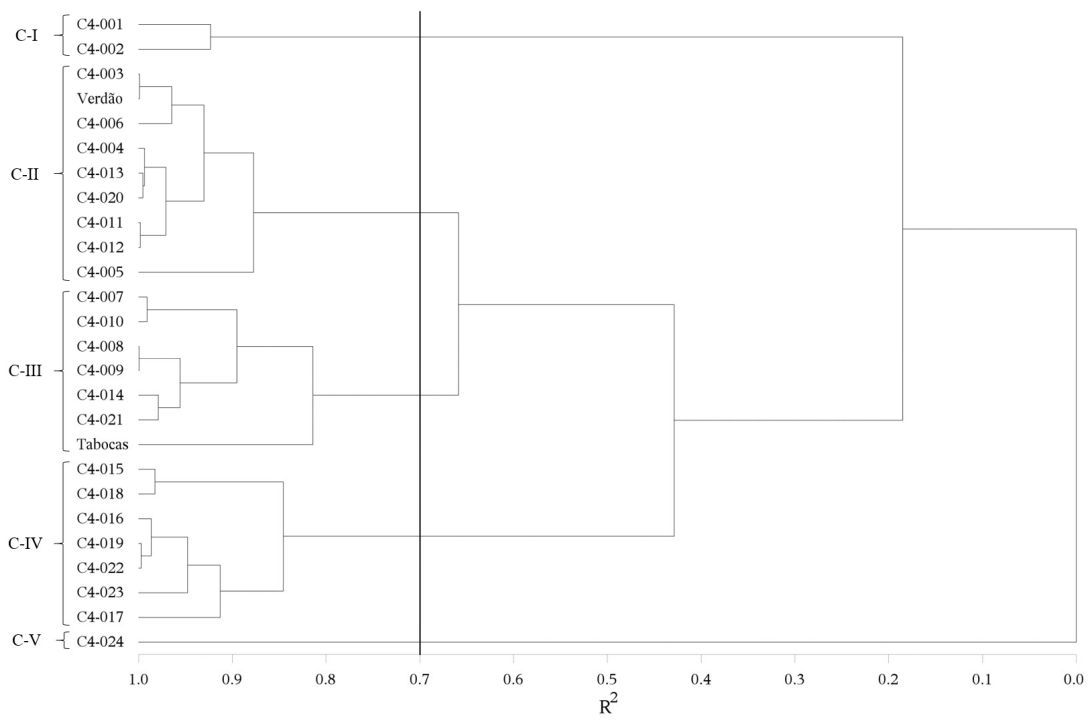

Figure 1. UPGMA clustering using the standardized mean Euclidean distance of averages of position for plant height, canopy diameter and fresh mass of shoot for all progenies, Recife, UFRPE, 2012.

\section{CONCLUSIONS}

The genotypes $\mathrm{C}_{4}-014, \mathrm{C}_{4}-015, \mathrm{C}_{4}-016$ and $\mathrm{C}_{4}-018$ can be selected to obtain a new population with high frequency of favorable alleles to shoot fresh mass.

The clusters C-II, C-III and C-IV can be included in the next cycle of recurrent phenotype selection to improve shoot fresh mass and plant height.

There is variability to be explored in the half-sib families of Verdão population for the evaluated traits, and it is possible to obtain genotypes with superior commercial quality compared to the cultivar of origin.

RESUMO: Esse trabalho objetivou avaliar o comportamento de progênies de meios-irmãos de coentro (Coriandrum sativum L.) para caracteres agronômicos. O experimento foi conduzido na Universidade Federal Rural de Pernambuco, sendo utilizado delineamento em blocos aumentados com 26 genótipos de coentro sendo avaliados 24 tratamentos regulares, representados pelas progênies de meios-irmãos de coentro e dois tratamentos comuns, 'Verdão' e 'Tabocas'. Essas progênies foram provenientes de 4 ciclos de seleção recorrente fenotípica, a partir da população Verdão, sendo selecionados para pendoamento tardio. Foram avaliados em campo os caracteres, altura da planta e diâmetro da copa e em virtude da colheita, a massa fresca da parte aérea. Houve diferença significativa entre as médias dos tratamentos para todas as variáveis analisadas. Segundo análise de variância e teste de media, há variabilidade passível de seleção nas progênies de meios-irmãos. Os genótipos $\mathrm{C}_{4}-014, \mathrm{C}_{4}-015, \mathrm{C}_{4}-016$ e $\mathrm{C}_{4}-018$ mostraram-se promissores quanto aos caracteres avaliados, quando comparados com as testemunhas comerciais. Os valores da herdabilidade no sentido amplo foram: 77,3, 815 e 95,8\%, para diâmetro da copa, massa fresca da parte aérea e altura da planta, respectivamente. Revelando que a maior parte da variância fenotípica se deve a variância genética. Portanto esses genótipos podem ser utilizados em programas de melhoramento de seleção recorrente para obtenção de cultivares de coentro adaptados a condição tropical.

PALAVRAS-CHAVE: Coriandrum sativum L. Blocos aumentados. Seleção recorrente. 


\section{REFERENCES}

ALVES, C. S.; PEIXOTO, J. R.; VIEIRA, J. V.; BOITEUX, L. S. Herdabilidade e correlações genotípicas entre caracteres de folhagem e sistema radicular em famílias de cenoura, cultivar Brasília. Horticultura Brasileira, Brasília, DF, v. 24, n. 3 p. 362-367, 2006. Disponível em: http://www.scielo.br/pdf/hb/v24n3/19.pdf. Acesso em: 15 jun. 2013.

BENITES, F. R. G. AND PINTO, C. A. B. P. Genetic gains for heat tolerance in potato in three cycles of recurrent selection. Crop Breeding and Applied Biotechnology, Viçosa, v. 11, p. 133-140, 2011. Disponível em: http://www.scielo.br/pdf/cbab/v11n2/05.pdf. Acesso em: 17 jul. 2013.

BERTINI, C. H. M.; PINHEIRO, E. A. R.; NÓBREGA, G. N.; LIMA DUARTE, J. M. Desempenho agronômico e divergência genética de genótipos de coentro. Revista Ciência Agronômica, Fortaleza, v. 41, n. 3, p. 409-416, 2010. Disponível em: http://www.ccarevista.ufc.br/seer/index.php/ccarevista/article/view/835. Acesso em: 20 ago. 2013.

BISOGNIN, D. A. Breeding vegetatively propagated horticultural crops. Crop Breeding and Applied Biotechnology, Viçosa, v. 11, n. S1, p. 35-43, 2011. Disponível em:

http://www.scielo.br/pdf/cbab/v11nspe/06.pdf. Acesso em: 14 jun. 2013.

BORÉM, A.; MIRANDA, G. V. Melhoramento de plantas. 6. ed. Viçosa: UFV, 2013. 523p.

BOX G. E. P.; COX, D. R. An analysis of transformations. Journal of the Royal Statistical Society. Series B (Methodological), Gainesville, v. 26, n. 2, p. 211-252, 1964.

CRAMER, C. S. Onion Trait Heritability and Response from Selection. Journal American Society

Horticultural Science. Alexandria, v. 5, n. 131, p. 646-650, 2006. Disponível em:

http://journal.ashspublications.org/content/131/5/646.full.pdf. Acesso em: 29 jun. 2013.

CRUZ, C. D. GENES - a software package for analysis in experimental statistics and quantitative genetics. Acta Scientiarum. Agronomy, Maringá, v. 35, n. 3, 2013. Disponível em:

http://periodicos.uem.br/ojs/index.php/ActaSciAgron/article/download/21251/pdf_1. Acesso em: 12 jun. 2013.

FARIAS NETO, J. T.; OLIVEIRA, M. D. S. P.; MULLER, A. A.; NOGUEIRA, O. L.; ANAISSI, D. F. D. S. P. Variabilidade genética em progênies jovens de açaizeiro. Cerne, Viçosa, v. 11, n. 4, p. 336-341, 2005. Disponível em: http://www.dcf.ufla.br/cerne/artigos/v11_n4_artigo\%2003.pdf. Acesso em: 26 jun. 2013.

MELO, P. C. T. Genetic improvement of vegetables: development of open-pollinated cultivars. Crop Breeding and Applied Biotechnology, Viçosa, v. 11, n. S1, p. 93-94, 2011. Disponível em:

http://www.scielo.br/pdf/cbab/v11nspe/15.pdf. Acesso em: 14 jul. 2013.

LUZ, J. M. Q.; ANDRADE, L. V. de.; DIAS, F. F.; SILVA, M. A. D.; HABER, L. L.; OLIVEIRA, R. C. de. Produção hidropônica de coentro e salsa crespa sob concentrações de solução nutritiva e posições das plantas nos perfis hidropônicos. Bioscience Journal, Uberlândia, v. 28, n. 4, 2012. Disponível em:

http://www.seer.ufu.br/index.php/bioscience journal/article/view/12544/9749. Acesso em: 14 set. 2013.

MELO, R. A.; RESENDE, L. V.; MENEZES, D.; BECK, A. P. A.; COSTA, J. C.; COUTINHO, A. E.; NASCIMENTO, A. V. S. Genetic similarity between coriander genotypes using ISSR markers. Horticultura Brasileira, Brasília, DF, v. 29, n. 4, p. 526-530, 2011. Disponível em: http://www.scielo.br/pdf/hb/v29n4/a14v29n4.pdf. Acesso em: 10 jun. 2013.

MELO, R. D. A.; MENEZES, D.; RESENDE, L. V.; WANDERLEY JUNIOR, L. J. G.; MELO, P. C. T.; SANTOS, V. F. Caracterização morfológica de genótipos de coentro. Horticultura Brasileira, Brasília, DF, v. 27, n. 3, p. 371-376, 2009a. Disponível em: http://www.scielo.br/pdf/hb/v27n3/v27n3a21.pdf. Acesso em: 13 set. 2013. 
MELO, R. D. A.; MENEZES, D.; RESENDE, L. V.; WANDERLEY JUNIOR, L. J. G.; SANTOS, V. F.; MESQUITA, J. C. P.; MAGALHÃES, A. G. Variabilidade genética em progênies de meios-irmãos de coentro. Horticultura Brasileira, Brasília, DF, v. 27, n. 3, p. 325-329, 2009b. Disponível em: http://www.scielo.br/pdf/hb/v27n3/v27n3a11.pdf. Acesso em: 18 out. 2013.

NASCIMENTO, W. M.; PEREIRA, R. S. Coentro: a hortaliça de mil e uma utilidades. Horticultura Brasileira, Brasília, DF, v. 23, n. 3, 2005. Nota de capa.

NUNES, M. U. C.; CUNHA, A. O.; CARVALHO, L. M. Efeitos de fontes alternativas de adubos orgânicos na produtividade de repolho x coentro em sistema ecológico de produção. Revista Brasileira de Agroecologia, Porto Alegre, v. 2, n. 1, p. 1234-1237, 2007. Disponível em: http://www.abaagroecologia.org.br/ojs2/index.php/rbagroecologia/search/advancedResu lts. Acesso em: 24 dez. 2013.

OLIVEIRA A. P. Desempenho de genótipos de coentro em Areia. Horticultura Brasileira, Brasília, DF, v. 25, n. 2, p. 252-255, 2007. Disponível em: http://www.scielo.br/pdf/hb/v25n2/23.pdf. Acesso em: 19 jun. 2013.

OLIVEIRA, A. P.; SILVA, V. R. F.; SANTOS, C. S.; ARAÚJO, J. S.; NASCIMENTO, J. T. Produção de coentro cultivado com esterco bovino e adubação mineral. Horticultura Brasileira, Brasília, DF, v. 20, n. 3, p. 477-479, 2002. Disponível em: http://www.scielo.br/pdf/hb/v20n3/14473.pdf. Acesso em: 01 set. 2013.

PEREIRA, M. F. S.; LINHARES, P. C. F.; MARACAJÁ, P. B.; MOREIRA, J. C.; GUIMARÃES, M. C. D. Desempenho agronômico de cultivares de coentro (Coriandrum sativum L.) fertilizado com composto. Revista Verde, Mossoró, v. 6, n. 3, p. 235-239, 2011. Disponível em:

http://gvaa.com.br/revista/index.php/RVADS/article/view/849. Acesso em: 02 jun. 2013.

SAS INSTITUTE INC. SAS/STAT®. User's Guide. 2. ed. Cary, NC: SAS Institute Inc, 2009. 7886 p.

SILVA, G. O. AND VIEIRA, J. V. Ganhos genéticos após seis ciclos de seleção em três populações de cenoura. Revista Ceres, Viçosa, v. 57, n. 6, p. 768-772, 2010. Disponível em:

http://www.scielo.br/pdf/rceres/v57n6/a11v57n6.pdf. Acesso em: 05 jun. 2013.

VASCONCELOS, E. S.; REIS, M. S.; SEDIYAMA, T.; CRUZ, C. D. Estimativas de parâmetros genéticos da qualidade fisiológica de sementes de genótipos de soja produzidas em diferentes regiões de Minas Gerais.

Ciências Agrárias, Londrina, v. 33, n. 1, p. 65-76, 2012. Disponível em:

http://www.uel.br/revistas/uel/index.php/semagrarias/article/view/5448. Acesso em: 17 jul. 2013.

VENCOSVSKY, R.; BARRIGA, P. Genética biométrica no fitomelhoramento. Ribeirão Preto: Sociedade Brasileira de Genética, 1992. 496p.

VENCOVSKY, R. 1987. Herança quantitativa. In: Paterniani E; Viegas GP (eds). Melhoramento e produção de milho. 2. ed. Campinas: Fundação Cargill. 1987. p. 137-214.

VERARDI, C. K.; RESENDE, M. D. V.; COSTA, R. B.; SOUZA GONÇALVES, P. Estimation of genetic parameters in rubber progenies. Crop Breeding and Applied Biotechnology, Viçosa, v. 12, n. 3, p. 185-190, 2012. Disponível em: http://www.scielo.br/pdf/cbab/v12n3/v12n3a04.pdf. Acesso em: 25 dez. 2013. 